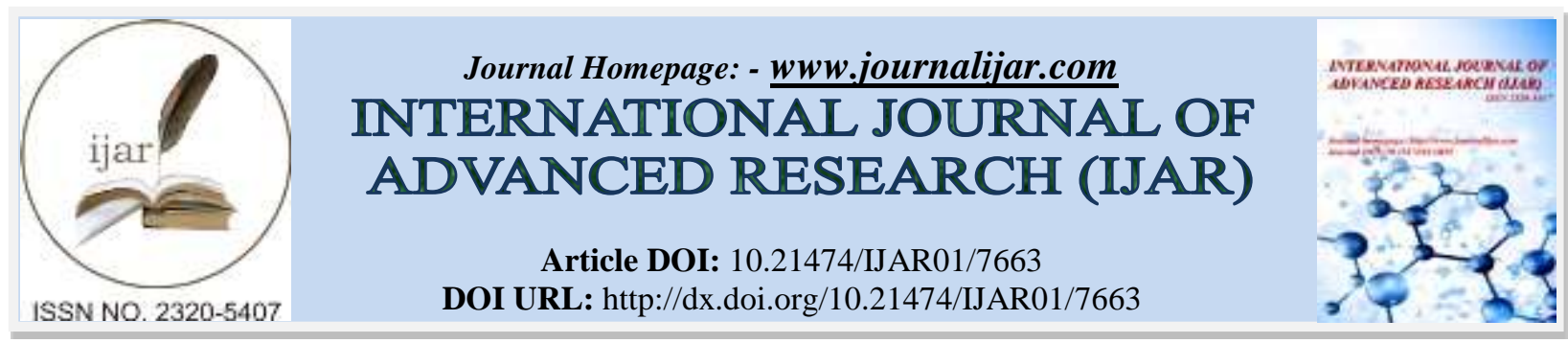

RESEARCH ARTICLE

\title{
A STUDY OF THE POLITICAL CHANGES IN UNDIVIDED BENGAL AND WEST BENGAL (1937 -
} 1967).

Dr. Ajanta Biswas.

Assistant Professor Department of History Rabindra Bharati University, Kolkata.

\section{Manuscript Info}

Manuscript History

Received: 04 July 2018

Final Accepted: 06 August 2018

Published: September 2018

\section{Abstract}

\section{Introduction:-}

In modern Indian historiography the period between 1937 and 1967 occupies a very significant place. This was the time when India made its transition form a half cock representative system of late colonial rule into a full-fledged democracy. India's democratization has touched on a major debate among historians. Some scholars have found in post-colonial Indian politics the promise of the growth of a large democratic system. Many years ago, Jyotirindra Dasgupta, an eminent political scientist boasted over the face that India was 'becoming democratic'. Others, particularly in recent times, have insisted that the democratic practice in India was merely a cover around an essentially undemocratic society, characterized by class, caste and gender inequalities. There is also a certain argument that the post-colonial administrative structure failed to outgrow its colonial origins. The modes of governance in India suggest the existence of an 'inheritor regime.'

It is against this larger backdrop that recent scholarship on post-colonial Indian history has tried to situate the gradual decline of the Congress system. The Congress system, as we study its burgeoning power in the 1950s, was based on a confederation of regional and local interests, which made for the so-called one party dominance in the immediate aftermath of independence. The elections of $1936-37^{1}$ demonstrated the overall dominance of the Congress, although in most of the Muslim majority provinces it has a minority status. Vinita Damodaran ${ }^{2}$ expresses her apprehension about the character that the Congress rule would take shape in future. The Congress in 1947 represented the promise of India's development as a modern industrial nation. The Five Year Plan was a measure of this commitment to national self-reliance. The party organization which had been growing since the 1920s in the rural areas provided the basis of support and mobilization during elections.

The objective of this paper is to examine the implications of these trends for the Congress in Bengal. The Congress Party in Bengal had always been faction-ridden. Its factionalism convinced a historian like John Gallagher ${ }^{3}$ that the erosion of the Congress base in Bengal had begun from the early 1930s.

Gallagher saw the Congress in decline from the 1930s. Later scholars like Joya Chatterji focused on how this decline was matched by the rise of Krishak Praja Party ${ }^{5}$ in the predominantly Muslim region of the province in eastern Bengal. Subsequently in the 1940s, the provincial Muslim League took the wind out of the KPP sail. In Joya Chatterji's opinion that was a major turning point in Bengal history which presaged the Partition in 1947.

Corresponding Author:- Ajanta Biswas.

Address:-Assistant Professor Department of History Rabindra Bharati University, Kolkata. 
Yet the Congress in the western districts of Bengal was still very powerful and once the province was partitioned, it established its hegemony over state politics in the state of West Bengal in independent India. Why was it then in 1967 that it lost its hold? How was the popular base of the Congress systematically eroded? These are the two central questions that the present paper seeks to answer. I approach these questions with a set of working hypothesis. In the first place, a dominant section of the Congress leadership of the state showed a certain indifference towards the refugees from Eastern Bengal, at times describing them as foreigners. Initially, the refugees adored the Congress. This is evident from the way they named the refugee colonies. The way the Congress leaders alienated them deprived it of a potential support base. The major beneficiary of such callousness of the Congress leadership was the Communist Party.

A second set of questions relates to the profound organizational decline of the Congress in Bengal because of certain erosion of rural base and partly due to the factional conflicts. How was this organizational decline matched with a gradual erosion of its rural base? In Bengal, however, the rural elite of rich peasants had a more heterogeneous caste composition, which weakened the particular strategy of mobilization of the Congress. More importantly, the history of how the small peasants were progressively alienated from the Congress because of its rich peasant bias in the countryside requires to be documented. This inevitably leads us to a study of the elections of the 1960s. Was it the fact that the Congress was basically winning by default in the absence of a concerted effort by the opposition to undermine the Congress dominance? Once the opposition showed signs of combining, it became difficult for the Congress to hold its ground. The close of the 1960s and the initial effort to create a multi-party opposition was the first major dent into the strong holds of the Congress power in the state. The growing power of the opposition coincided with food scarcity in the state from the middle of the 1960s. The Food Movement which was caused by food shortages and rising prices set the stage for the opposition to take a major initiative towards unseating the Congress from power. ${ }^{6}$ The story of the decline of the Congress, therefore, calls for an analysis of how at the initiative of the Communist Party, the left in Bengal was successful in creating major strong holds for the anti-Congress forces.

The Congress bagged 54 seats and got single majority in the election of 1937. The other two remarkable political parties, the Muslim League and the KPP got 40 and 35 seats respectively. In this period,the KPP led by Fazlul Huq got a huge support from rural Bengal having committed to solve the real problems of the peasantry. Though all the peasants did not acquire the voting right, but a large number of peasant class got this right and in that context the importance of the peasant class was increased in the feudal - bourgeois politics. The advancement of the bourgeois politics got its momentum exploiting the peasants of Bengal. In this context, it should be noted that the Muslims were the majority as a community among the peasants. The oppression of the Jotedars and Zamindars on them was immense. In these circumstances, the Muslim politicians made the peasants their carrier to serve their own class interest. They started to organize the meetings and conferences to build the movements for election on the basis of the demands of the peasantry. In this aspect, the role of the Bengal Provincial Congress was different, because the Caste-Hindus were on the steering-role among the Zamindars, Jotedars and the money-lenders. These Caste-Hindus were in the leading role in Congress. That is the cause why the Congress Party did not bother much about the peasant-politics.

In spite of that, after the election of 1937, the Congress was the major party in Bengal. But, it is to be noted that in spite of their majority, Congress failed to form the ministry. After 1937, the meeting with the KPP to form a coalition government could not be successful due to the issue of the release of the prisoners. It was the demand of Congress that all political prisoners should be released. On the other hand, the KPP was firm to give priority to the interest of the peasant class. In these circumstances, the KPP led by Fazlul Huq and Muslim League jointly formed the ministry in Bengal.

After 1937, the internal feud of the main opposition Congress Party became open to all. In 1925, after the demise of Chittaranjan Das, one of the most popular heroes of the political scene of Bengal, was Subhas Chandra Bose. He was expelled from the Congress leadership in such a manner that a major part of the politically conscious people started to feel apathy on Congress. This mentality became more acute when the intellectuals of this province were obsessed with the total decay of Bengal. In this perspective, Subhas Chandra Bose was the face of protest of Bengal against the central leadership of Congress Party.

When the Congress was divided into many factions, at that time the increasing popularity of the KPP was most marked; afterwards the supremacy of the Muslim League among the Muslims and the influence of the Hindu Mahasabha on the wealthy Hindu community of Bengal in the first part of the 1940s put obstacles on the power of 
Congress Party. The Congress became weaker as these trends became acute in the decade of the 1940s. In spite of this, the Quit India movement ${ }^{7}$ showed that the organization of the Congress Party was still active at least in the rural area of West Bengal.

The organisational power of Bengal Provincial Congress became gradually weak due to these conflicts which had been formed by the structural crisis of the Provincial Congress of undivided Bengal. In the primary stage, due to ideological cause, different social groups gathered under the banner of Congress Party. Later, especially from the decade of the 1920s, the Congress tried to assimilate the different interests of these social groups with idealism. As a reaction of this effort, the conflicts between the nationalistic ideology and these social groups became open, the conflicts began to appear with different issues. The main conflict between the imperialism and nationalism started to be faded. Naturally, the groupism ${ }^{8}$ became predominant on different issues in different periods, which made the Provincial Congress Party gradually weak from the days of the 1930s to the 1960s.

Let us now discuss the different characteristics of Congress politics of undivided Bengal in the period from 1937 to 1947. The coalition Ministry of the KPP and the Muslim League lasted till 1941. At the end of 1941, the party of Fazlul Huq left the coalition and formed the Progressive Assembly Party. In March 1943, the Progressive Coalition Government led by Fazlul Huq was dissolved and a Muslim League Ministry led by Khawaja Nazimuddin was formed. In March 1945, the Nazimuddin Ministry had to resign. Then the Ministry led by Suhrawardy was formed in undivided Bengal. During this period, the characteristic speciality of the Congress was the vacillating tendency of its members. After the elections many Congress leaders tried to grab the power by mutual understanding. Even when the understanding by the party faced failure, the Congress leaders started to share power personally by the personal connection, communication and by tactical methods. The KPP, Muslim League and the Hindu Mahasabha did not have any similarity in their ideals with Congress; still the Congress leaders like Nalini Ranjan Sarkar, Santosh Kumar Basu, Tulsi Ranjan Goswami respectively joined the KPP, Muslim Legaue, Hindu Mahasabha Ministry. In the mean time, the influence of the radical group was increased inside the Congress organization. After the election of 1937, due to the conflict between the radical path and the conservative path of the Congress organization, the Congress became powerless to resist the strike of the Legislative Assembly. In the year 1937 when the Bengal Prajasatwa Bill (Amendment) was presented to the Legislative Assembly, the radical group of the Congress retreated. The radical group did not have any other alternative than to oppose the bill in order to retain the support of the party with them. Again, we can observe that when the Congress gave the way to the Mahajani Bill to be accepted without any challenge, the people who had the economic interest, started thinking that the radical group of the Congress would not allow them to make profit from the investment. At that time the Zamindar group and the businessman group started to think de novo whether they would support this party or not, and it was seen at the end of the 1930s and in the beginning of the 1940s this wealthy group became more interested on Hindu Mahasabha than that on Congress.

The Tripuri Congress and in this way the breakup of Bengal Provincial Congress caused the gradual decrease of influence of radical group on Congress organization. After expelling Subhash Chandra Bose and his close associates one by one without any hesitation, Congress Party could give a foothold on the Hindu-base. The Hindu businessman and Zamindars of Bengal took the decision to support the Congress again; it was proved in the election of 1945-46. This election of 1945-46 proved that the Congress Party had defeated one of its competitors in the struggle of capturing votes.

The partition of 1947 had changed the political scene of Bengal. This situation had obviously changed the stands of all political parties defying the equilibrium of power, generally of those groups and parties, whose stronghold was in East Bengal - the political parties which were influential in East Bengal. Then they started to form the new groups and to build their base in the politics of West Bengal, so that they could recover from their helpless condition. After independence, the then leadership of Provincial Congress came into power in many other provinces and many of those parties had the experience of participating in the Provincial Governments which were formed between 1937 and 1939. But, in West Bengal, the situation was different. Here the Congress was never in power before 1947. In this period, the conflict started in every sphere of West Bengal Provincial Congress. The first noteworthy group to be mentioned is the Hooghly Group in the Post-Independence Provincial Congress. At the time of the Partition, the Congress was such an organisation where the members coming from East Bengal used to enjoy the privilege. As per its constitutive rules, the All India Congress Committee would have to be formed by the representatives of the Provincial Congress Committee. The old rule had indicated that the number of delegates would depend on the 
population of the district. Due to the huge population, the eastern districts could send more delegates to the A.I.C.C. in comparison to the western districts of the undivided Bengal.

In the month of July 1947, the Congress Working Committee took the decision that the Provincial Committees of the divided provinces like Bengal and the Punjab would continue their normal work until the Congress would write their new constitution, but this Working Committee could not start this programme till the middle of 1948. In this way, the delegates of East Bengal could continue their supremacy in the Bengal Provincial Committee another one year after the Partition ${ }^{9}$. The Hooghly group was very much active to break this supremacy. This Hooghly group got the advantage due to the new orientation after the Partition, because most of the leaders from East Bengal left their homeland for the other side of the barbed-wire. At first the Hooghly Group became able to dethrone the first Chief Minister (it was called 'Premier' at that time) Prafulla Chandra Ghosh (Mr. Ghosh was the follower of Gandhi Colony of Abhay Ashram, Kumilla, who became the Chief Minister for only 5 months from the $15^{\text {th }}$ August, 1947 to the $15^{\text {th }}$ January, 1948). Then the Hooghly group supported Dr. Bidhan Chandra Roy. Their friendship with Dr. Roy lasted till his death in 1962. Then one of the partners of the game of 'King Makers', Prafulla Chandra Sen became the Chief Minister.

After Independence, in 1952, 1957, and even in the year 1962, the Congress could manage to retain its vote bank unharmed, because, it can be assumed that in the rural Bengal, former Zamindars and Jotedars might lose their legal power, but in reality still they had the control over the land. These former land-owners kept their feudal power unchanged in the village society. The middle and small peasants could not build their own power to destroy the control of these land-owners. Now the question is: Why did the Congress try to look after the interests of the former Zamindars-Jotedars neglecting the interests of the poor people of the lower strata in the rural area of postindependence period? It is shown in this article that there were only two ways for the Congress Party to strengthen their organization; either they had to imply the Land reforms Act of $1953-54^{10}$ for the support of the peasantry and in this way to strengthen their mass-base, or to recognize the pre-independence pact between the Congress and the traditional landed class of the society. As the Congress leadership came mainly from these traditional landed classes, the powerful Hooghly Group gave priority to the later process. In consequence, the Land Reforms Act was not implemented successfully; on the other hand, the bonding between Congress and the rural elite became very strong in this period. They invested the residue from the land to different ventures. This group profited a lot from the landmarket which was formed due to the refugee rehabilitation. They started to control the urban and rural economy. The Hooghly group of Bengal Provincial Congress had a relation of keen interest with these people. So they kept the Congress vote bank intact.

Though the number of seats won by the Congress was more, but the difference in the percentage of votes in comparison with the leftists was nominal. ${ }^{11}$ Side by side the failure of Congress government to solve the socioeconomic problems in post-independence era and their organisational weakness became apparent, and this crisis was utilised by the leftists and in this way they came to limelight as a political power. The leftists led the mass movements. The Food Movement of $1959^{12}$ and $1966^{13}$ led by the leftists was the outcome of this mass-movement. The leftist parties were rapidly expanding their organisational base in the districts. The peasant front of the Communist Party of India (Marxist) was known as Krishak Sabha which expanded their organisation everywhere, even in the remote corners inhabited by the tribes. The Food Movement made a change in the village-politics of rural West Bengal; the committees against price-hike and famine led by the Left parties were formed, which consolidated the public opinion and organised the movement against the failure of Congress Government to stop the price-hike. On 18th February 1966 the members of 'the opposition painted a grim picture of the food situation in the districts and sharply criticised the Government policy. The new food policy had failed but the Government did not have the courage to admit it. The causes of the failure according to Mr Somnath Lahiri (CPI), were the Government's inability to procure paddy from big Jotdars. Its refusal to nationalise rice mills and its reluctance to secure the cooperation of the Opposition. Mr Lahiri and other critics warned the Government that the situation is slipping from its grasp and if it didn't change its food policy incidents similar to those that had happened in some districts might recur.' ${ }^{14}$ The spark which was kindled by the Food Movement was not extinguished by the defeat of the Congress Party. The organised move was started against the benami land of the Jotedars at the time of the Food Movement of 1966. This militant and armed class-struggle was turned to Naxalbari Movement in the rural areas.

The movement ${ }^{15}$ of the Leftists was directed in two ways - 1) Political Propaganda, 2) Cultural Movements. The ideological movement in these two ways against the Congress helped to bring the middle-class of villages and cities, professionals and labour-class into the main stream of left ideology. In this way of anti-Congress leftist movement, 
many organizations were formed. These mass-organizations were the main base of the leftist movement. Simultaneously, from the 1950s, the organisational lapse of Provincial Congress to solve the refugee-problem in West Bengal became pronounced. As a major plan of Congress leadership of West Bengal came from the SouthWest part of West Bengal, they had an indifferent, often neglecting attitude towards the refugees. Not only the provincial leadership, but also the central leadership was not free from this parochial attitude. The Congresssupported people of West Bengal used to enjoy facilities to the sphere of rehabilitation by distributing the land and relief material. Hence the leadership of the refugee organizations gradually went to the hands of the leftists. The role of the United Central Refugee Council (hereinafter UCRC ${ }^{16}$ ) or Sara Bangla Bastuhara Samity was noteworthy in this aspect. The negative and obstinate attitude of the Congress Government to the movement for the increase of the wage of the factory-workers, increase of facilities of the middle-class professionals and their demand for the increase of salary brought their organisations under the control of the Leftist leadership. At the same time, the economic, social and political programmes of the Leftists to solve the national problems made a major part of the Bengali middle class much closer to the Leftist politics. A New Leftist cultural movement was constructed by them. In the meantime, the division in Bengal Provincial Congress and the rise of 'Bangla Congress' ${ }^{17}$ under the leadership of Ajoy Mukherjee made the Leftist political movement stronger and prepared the scene of capturing the power by the leftists in 1967.

\section{References:-}

1. Dilip Banerjee, Election Recorder - An Analytical Reference, Bengal /West Bengal, 1862-2006, Kolkata, 2006; pp: 49-51.

2. Vinita Damodaran, Broken Promises : Popular Protest, Indian Nationalism and the Congress Party in Bihar 1935 -46, Delhi, 1992.

3. John Gallagher, 'Congress in Decline: Bengal 1930 to 1939', Modern Asian Studies, 7, 3, 1973.

4. Joya Chatterji, Bengal Divided : Hindu Communalism and Partition, 1932 - 1947, Cambridge, 1994, pp: 123124 (Bengali Version).

5. Hereinafter called the KPP.

6. 'Food Policy for West Bengal', West Bengal Committee C.P.I. in Jyoti Basu (Ed.), Documents of the Communist movement in India, Vol-VIII, 1957-1961, Calcutta. p: 25 (in this article, West Bengal Committee C.P.I. elaborately explained the food policy for West Bengal)

7. For details, see Hitesh Ranjan Sanyal, Swarajer Pathe, (in Bengali) Kolkata, 1994; p: 119-166; Ladli Mohon Raychaudhury(ed.). The Quit India Movement 1942. A Collection of Documents, Vol 1, Goverment of West Bengal, 1993, pp:109-158.

8. Prasanta Sengupta, The Congress Party in West Bengal: A Study in Factionalism, 1947-86, Calcutta, 1988, Preface; Joya Chatterji, op.cit. ; Joya Chatterji, The Spoils of Partition: Bengal and India, 1947-1967, Cambridge University Press, 2007; see specially Chapter on 'Political reconstruction and change: Congress government and politics, 1947-1967'.

9. Prasanta Sengupta, ibid. p:28-29; Joya Chatterji, ibid. pp:214-217.

10. Sugata Bose, Peasant Labour and Colonial Captial : Rural Bengal since 1770 ( The New Cambridge History of India Vol iii 2), Cambridge University Press, 1993 pp: 174-177.

11. Dilip Banerjee, op.cit. pp:161-162.

12. Swadhinata,(editorial) $8^{\text {th }}$ September, 1959 in Suranjan Das and Premansukumar Bandyopadhyay, Food Movement of 1959: Documenting a Turning Point in the History of West Bengal, K.P. Bagchi \& Co. Kolkata, 2004, p: 249-250.

13. For detailed see Anwesha Chakrabarti, "Food Movements in West Bengal - 1959-1966", unpublished Ph.D thesis thesis in History, Rabindra Bharati University,2014.

14. The Statesman, February 19, 1966

15. Anil Biswas (Ed.), Banglar Communist Andolon: Dolil O Prasongik Tathya, Chaturtho Khando, Calcutta, 2004

16. Prafulla K. Chakrabarti, The Marginal Men: The Refugees and the Left Political Syndrome in West Bengal, Naya Udyog, 1999, pp:67-78

17. Prasanta Sengupta, op.cit. p:109. 